\title{
Reconnaissance sediment budgets for Lynn Valley, British Columbia: Holocene and contemporary time scales
}

\author{
David Campbell and Michael Church
}

\begin{abstract}
Volumes of erosional and depositional landforms were estimated by reconnaissance methods in a steep, forested drainage basin in the Coast Mountains, British Columbia, to examine what insight might be gained into the sediment budget in the absence of direct measurements of sediment transfer processes. Sediment transfers in postglacial and contemporary time were inferred on hillslopes, from hillslopes to stream channels, and within stream channels. Data were collected by aerial photographic analysis and field observation. Postglacial sediment sources are major gullies created by debris slides and flows, failures in glaciolacustrine terraces, and stream channel degradation. Depositional landforms consist of talus slopes and colluvial and alluvial fans. Contemporary sediment sources include debris slides and flows in established gullies and minor processes on hillslopes. Debris slide and debris flow volumes were calculated, and other processes were estimated from regional values. Erosion rate averaged over postglacial time is $276 \mathrm{t} \cdot \mathrm{km}^{-2} \cdot \mathrm{a}^{-1}$ $\left(0.15 \mathrm{~mm} \cdot \mathrm{a}^{-1}\right.$ surface lowering), with gullies and stream channel degradation contributing 170 and $82 \mathrm{t} \cdot \mathrm{km}^{-2} \cdot \mathrm{a}^{-1}$, respectively. A terminal alluvial fan provides an independent check of the results. In contemporary time, erosion rates are calculated to be $350 \mathrm{t} \cdot \mathrm{km}^{-2} \cdot \mathrm{a}^{-1}$, with debris flows and slides contributing nearly all of this sediment. The contemporary rate is probably perturbed by recent land use history. Mass-movement processes appear to be the dominant mechanism of sediment transfer and, contributions from Pleistocene valley deposits have declined significantly during Holocene time.

Résumé : Les volumes de terrain érodés et déposés ont été estimés par des méthodes de reconnaissance dans un bassin de drainage, boisé, à pentes abruptes des montagnes côtières de la Colombie-Britannique afin d'étudier quelles connaissances sur le budget sédimentaire pourraient être acquises en l'absence de mesures directes du processus de transfert de sédiments. Les transferts de sédiments à l'époque post-glaciaire et contemporaine ont été inférés sur les flancs des côtes, des flancs des côtes vers les chenaux des rivières et dans les chenaux des rivières. Les données proviennent de l'analyse de photographies aériennes et d'observations sur le terrain. Les sources de sédiments post-glaciaires sont des ravines créées par des glissements et des coulées de débris, des effondrements de terrasses glacio-lacustres et la dégradation de chenaux. Les formes de terrain créées par déposition comprennent des tabliers d'éboulis et des deltas colluviaux et alluvionnaires. Les sources contemporaines de sédiments comprennent des glissements et des coulées de débris dans des ravines établies et des processus mineurs sur des pentes. Les volumes des glissements et des coulées de débris ont été calculés et d'autres processus ont été évalués à partir de valeurs régionales. La moyenne du taux d'érosion pour la période post-glaciaire est de 276 tonnes $\mathrm{km}^{-2} \mathrm{a}^{-1}$ (abaissement de la surface de $0,15 \mathrm{~mm} / \mathrm{a}$ ); les ravines et la dégradation des chenaux des ruisseaux contribuant respectivement 170 et 82 tonnes $\mathrm{km}^{-2} \mathrm{a}^{-1}$. Un delta alluvionnaire terminal permet une vérification indépendante des résultats. À l'époque contemporaine, les taux d'érosion sont calculés comme étant 350 tonnes $\mathrm{km}^{-2} \mathrm{a}^{-1}$ et les glissements et des coulées de débris y contribueraient pour la presque totalité. Le taux contemporain est probablement perturbé par l'utilisation récente du terrain. Les processus de mouvements de masse semblent être le mécanisme dominant de transfert de sédiments et les contributions provenant des dépositions dans les vallées au Pléistocène ont diminué de façon significative durant l'Holocène.
\end{abstract}

[Traduit par la Rédaction]

\section{Introduction}

The purpose of this study is to examine the possibility of establishing an approximate sediment budget in a drainage basin using reconnaissance methods based on measurements of contemporary landforms. The study is conducted within the drainage basin of Lynn Valley in the southernmost Coast Mountains of British Columbia. In particular, sediment transfers

Received 5 July 2002. Accepted 23 December 2002. Published on the NRC Research Press Web site at http://cjes.nrc.ca on 26 May 2003.

Paper handled by Associate Editor R. Gilbert.

D. Campbell. Department of Geography, The University of British Columbia, Vancouver, BC V6T 1Z2, Canada.

M. Church. ${ }^{1}$ Department of Geography and Peter Wall Institute for Advanced Studies, The University of British Columbia, Vancouver, BC V6T 1Z2, Canada.

${ }^{1}$ Corresponding author (e-mail: mchurch@geog.ubc.ca). 
are examined in postglacial and contemporary time. The long-term budget is essayed because of the growing interest in landscape evolution within the Holocene Epoch, and because it seems feasible to establish meaningful initial conditions at the close of glaciation. The contemporary sediment budget is studied because it is of interest in practical matters of land management, even though there almost never are any measurements of sediment transfer processes available at particular sites in British Columbia, or in most other places. The two time frames might also provide insight into how landscape processes have changed through time.

Sediment transfer is the result of sediment movement on hillslopes, from hillslopes to stream channels, and within stream channels. Significant mass-wasting mechanisms for sediment transfer on hillslopes in the study area are rockslides, debris slides, and debris flows. Moving water mobilizes sediment primarily by means of gully, stream bank, and channel bed erosion. Because we have no information on specific mechanisms of sediment mobilization, attention is focused on the sources of the sediment and on an examination of where sediment is transferred and stored in the drainage basin. Hence emphasis is placed on the inventory and analysis of erosional and depositional landforms. A chart of possible transfer routes is given in Fig. 1. Sediment is derived from weathered bedrock or surficial materials and can be mobilized by mass-wasting processes or by fluvial entrainment. Upper slopes represent regions of erosion where material is transferred predominantly by mass wasting to lower slopes or to stream channels. Erosional features, dominantly gullies, represent this loss of material. Lower slope areas accumulate material from upper slopes and store sediment in colluvial fans and talus slopes. Lower slopes are adjacent to stream channels, and sediment is transferred to them by mass wasting or riparian erosion. Stream channels are conduits for sediment movement, and material can be accumulated and stored or lost due to transport of material downstream, represented by channel aggradation and degradation, respectively.

Sediment budgets are a useful means to examine sediment movement in a drainage basin (Dietrich and Dunne 1978; Dietrich et al. 1982), particularly for reconnaissance investigations when few or no process measurements are available (Reid and Dunne 1996). Sediment budgets have been used in the Pacific Northwest region to assess geomorphic processes (e.g., Swanson et al. 1982; Roberts and Church 1986; Jordan and Slaymaker 1991). In this study, the sediment budget principle is applied to study sediment movement in Lynn Valley. This is a synoptic investigation (i.e., one made at a particular moment in time, without benefit of direct observations of sediment transfers) that nevertheless attempts to focus on geomorphic processes over landscape evolutionary time and in contemporary time.

Another intent of this study is to examine the relative importance of various sediment transfer processes to total sediment mobilization over geomorphologically and practically significant periods. The operational objectives are, then, to identify the sources of sediment, infer the processes of transfer, and assess the absolute and relative contribution of the dominant processes in a steep catchment in the British Columbia Coast Mountains. The sediment budget is restricted by former glaciation to a period of 14000 years. A comparison is made with the similarly approximated recent sediment budget to
Fig. 1. Conceptual flow diagram of sediment transfers in a mountain drainage basin. Boxes indicate sediment storage elements. Adapted from Roberts and Church (1986, their fig. 1).

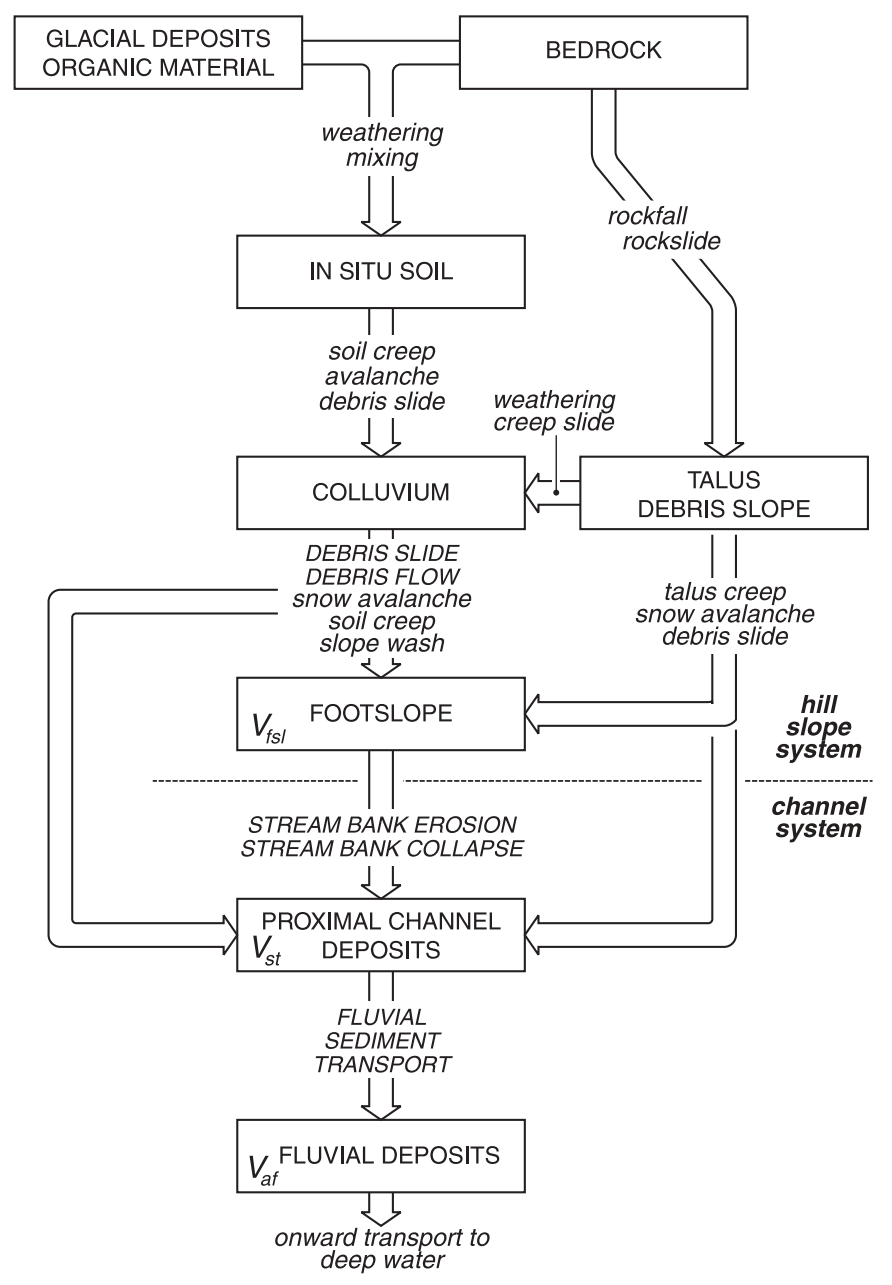

gain some insight into the relevance of sediment budgets based on contemporary measurements in the context of geomorphological investigations.

\section{Geography}

Lynn Valley (Fig. 2) is located north of the City of Vancouver at the southwestern extremity of the Coast Mountains of British Columbia. Lynn Creek, the major stream of the watershed, is fed from five significant tributaries. From assessment of Terrain Resource Information Mapping (TRIM), 1 : 20000 scale digital topographic map data (sheets 92G.025, 92G.035, 92G.045, and 92G.046), Lynn Creek is a fifth-order stream system (Strahler 1952). Downstream of Norvan Creek it has a gradient of 0.021. The mouth of Lynn Creek discharges into Burrard Inlet, where sediment removed from the watershed has accumulated into an alluvial fan and delta with a gradient of 0.011. Armstrong and Hicock (1979) report that the fan is a medium- to coarse-gravel body constructed in postglacial time. The fan surface consists of gravel right to the inlet. This and the substantial gradient indicate that finer sediments are removed into deep water.

The watershed area upstream of the fan is $43.7 \mathrm{~km}^{2}$. The 
Fig. 2. Location and topography of Lynn Valley (National Topographic System map 92 G/7) and the distal alluvial fan. The shaded area on the map represents the area within which urban development has occurred. Between the northern limit of the urban area and the head of the fan, Lynn Creek flows through a bedrock canyon.

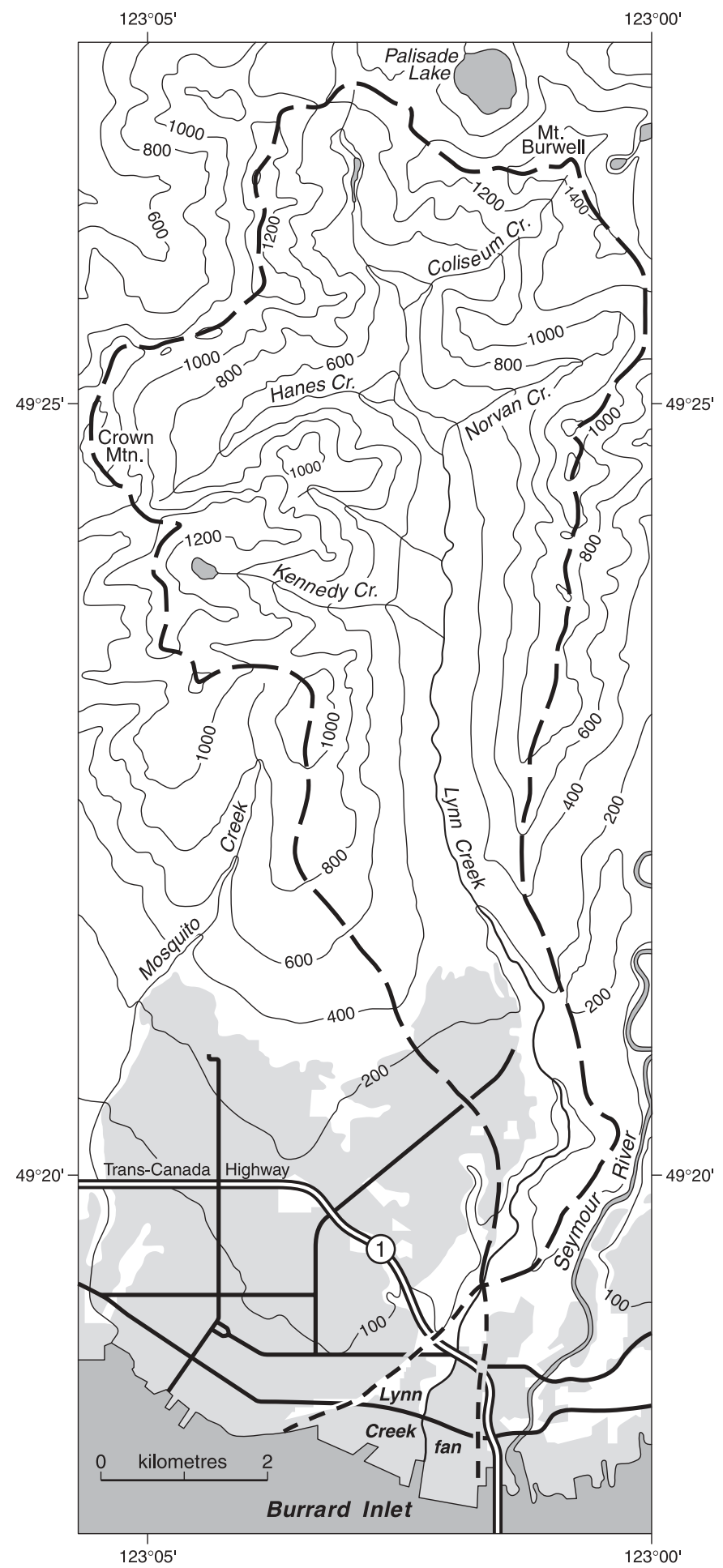

area is wet, with annual precipitation of $2700 \mathrm{~mm}$ at a gauge near the southern end of the valley, but it is estimated that precipitation around the headwater peaks may approach $5000 \mathrm{~mm}$. Lynn Valley was logged in the first half of the 20th century, mainly before 1940 , but is now protected as a park within the Greater Vancouver Regional District. It is entirely forested and contains no roads.

The study area has undergone repeated episodes of glaciation, the most recent of which, the Vashon Stade of Fraser Glaciation, ended approximately 14000 calibrated (cal) radiocarbon (calendar) years BP. (Most references to the late Quaternary history of the region refer consistently to radiocarbon years; for sediment budget purposes, of course, we require calendric years. Equivalences based on the radiocarbon calibration of Stuiver et al. (1998) are given by Kovanen and Easterbrook (2002).) Dating of the final deglaciation on the Vancouver north shore is not well constrained, but a large number of dates from the lower Fraser Valley, immediately east (Kovanen and Easterbrook 2002), indicates that marine incursion followed the breakup of Vashon ice in the period 13500 to 14000 cal years BP. The subsequent Sumas readvance did not reach the Vancouver area (Clague et al. 1997; Kovanen and Easterbrook 2002). We conclude that, for our purposes, 14000 years is the best approximation of the postglacial period in Lynn Valley.

During the Vashon Glaciation the Cordilleran Ice Sheet overrode the entire landscape. The physiography reflects this history, the accentuated, U-shaped main valley having steep hillslopes and the peaks being rounded by glacial erosion. Overall, $22.3 \mathrm{~km}^{2}$ (or $51 \%$ ) of Lynn Valley is steep (>30 gradient) terrain. Elevations of the watershed divide are in the order of 1000-1500 m, with local relief in the order of $1000 \mathrm{~m}$.

Upper slopes are typically exposed bedrock consisting predominantly of Upper Jurassic to Tertiary plutonic rocks (Roddick 1965), mostly granodiorite and quartz diorite, that do not weather readily in the contemporary environment. Till, derived from the local bedrock and typically $1 \mathrm{~m}$ in thickness, occurs on the middle and lower slopes. Greater thicknesses are found in depressions throughout the basin. Till and derivative colluvium constitute the major soil-forming medium above the valley floor. Mass wasting is concentrated in the depressions, where drainage rapidly concentrates, and takes the form of debris slides and debris flows (Innes 1983; Costa 1984) that run out onto colluvial fans at the slope base. The depressions are thereby transformed into steep and steep-sided gullies. Open slope failures are dominantly rockfalls from exfoliation sheets on the granodiorite, which contributes to talus development on the lower slopes. The valley fill is predominantly glaciofluvial material that has been terraced due to river degradation during the Holocene Epoch. Fine-grained glaciolacustrine deposits occur at the southern end of the valley at an elevation of approximately $300 \mathrm{~m}$.

\section{Methods}

Sediment yield is the amount of sediment that is transferred by any given process or event from a defined area through a particular measurement section. A sediment budget for a defined region can be expressed in terms of sediment yield as

$$
\text { [1] } O=I-\Delta S
$$

where $O$ is the sediment output, $I$ is the sediment input, and $\Delta S$ is the change in sediment in storage (positive for an increment to storage), all for the same area. 
To estimate the yield of sediment at various sites within the study basin, aerial photographs were analysed in conjunction with $1: 20000$ scale TRIM series topographic maps to estimate volumes of landforms and erosional events. The analysis was supplemented by studies of published data to estimate yield rates of certain minor processes. The aerial photographs were obtained in 1996 for the Province of British Columbia and have a nominal scale of $1: 20000$. In the valley bottom, however, elevation is near $300 \mathrm{~m}$ and the actual scale is close to $1: 19000$, and at an elevation of $1000 \mathrm{~m}$ it is $1: 16800$. A working scale of 1 : 19000 has been used for measurements on the aerial photographs, except for erosion features distributed along the hillslopes, where a scale of 1 : 18000 (implying a median elevation of $600 \mathrm{~m}$ ) was adopted. These conventions probably introduce a small positive bias into measurements along the valley, where most of the measured landforms are located and the true scale probably is slightly larger, and small biases for measurements of the gullies and rockfall sources, which extend downslope from near the ridge tops. We estimate these biases to be no more than $\pm 5 \%$. Linear measurements were made with ruler accuracy of $0.5 \mathrm{~mm}$, and therefore there is an associated error of $\pm 5 \mathrm{~m}$.

\section{Postglacial sediment transfers}

Two time scales were examined: postglacial time and contemporary time. For the purposes of this study, the postglacial period is assumed to be the period since deglaciation ca. 14000 BP. Subsequent landform evolution is supposed to have occurred in a nonglacial setting. The disappearance of glaciers would not, however, have been instantaneous. Sediment transfer is likely to have been of a greater magnitude during glacial recession as the landscape responded to the effects of glaciation (Church and Ryder 1972; Lian and Hickin 1996). Increased fluvial action of meltwater and large amounts of unstable till deposited on steep hillslopes would produce a geomorphologically active landscape. Postglacial erosion, sediment transfer, footslope development, and floodplain development are assumed to have occurred since $14000 \mathrm{BP}$, but it is recognized that all of these events commenced during glacial recession. We have paid particular attention to erosion of steep hillslope gullies, downcutting of valley fill, and erosion of glaciolacustrine deposits.

\section{Specification of the sediment budget}

To examine the relations between different transfer mechanisms and various storage elements it is helpful to specify eq. [1] in terms of budgets for slope-to-stream transfers and stream-to-stream transfers. Because our basic measurements are landform volumes, we specify volumes in our equations. We require mass terms for commensurability of the terms, however, hence material bulk densities are also specified. Input refers to the movement of sediment from its original position within the basin. Hillslope erosional landforms represent regions where sediment and rock material have been evacuated and transferred downslope. The erosional volume of material mobilized from gullies and steep slopes $\left(V_{\mathrm{hsl}}\right)$, which is an abstraction from storage on the upper hillslopes, is interpreted as the input of sediment to lower hillslopes $(I)$. The storage of material on hillslopes $(\Delta S)$ is viewed in terms of the volume of footslope landform development $\left(V_{\mathrm{fs}}\right)$. These accumulations are talus slopes, talus cones, and debris fans. Combining these terms the sediment budget for the slopes becomes

$$
O_{\mathrm{sl}}=\rho_{\mathrm{hsl}} V_{\mathrm{hsl}}-\rho_{\mathrm{fsl}} V_{\mathrm{fsl}}
$$

where $O_{\mathrm{sl}}$ is the mass output of material from hillslopes to the stream system; and $\rho_{\mathrm{hsl}}$ and $\rho_{\mathrm{fsl}}$ are the hillslope and footslope bulk densities, respectively. An implicit constraint in this equation is that, in the long run, $V_{\mathrm{hsl}} \geq V_{\mathrm{fsl}}$.

For stream-to-stream transfers, the sediment budget is written as

$$
O_{\text {str }}=I_{\text {str }}-\rho_{\text {str }} \Delta V_{\text {str }}
$$

where $O_{\text {str }}$ is the output of material contributed from stream-to-stream transfers; $I_{\text {str }}$ is the input of sediment into the stream, which is considered to be equivalent to the output from hillslopes $\left(O_{\mathrm{sl}}\right) ; \rho_{\mathrm{str}}$ is the stream sediment bulk density; and $\Delta V_{\text {str }}$ is the change in storage within the stream system. $\Delta V_{\text {str }}$ can be a positive value, representing net channel aggradation, or a negative value, representing net channel degradation, and the term includes both bed and bank erosion.

The output of material from the system is interpreted to be the alluvial fan deposited from Lynn Creek into Burrard Inlet plus material lost to deep water. This relation is represented as

$$
O_{\text {str }}=\rho_{\mathrm{af}} V_{\mathrm{af}}+\rho_{\mathrm{dw}} V_{\mathrm{dw}}
$$

where $V_{\text {af }}$ represents the volume of material accumulated in the alluvial fan; $\rho_{\mathrm{af}}$ and $\rho_{\mathrm{dw}}$ are the terminal alluvial fan and deep water material bulk densities, respectively; and it is assumed that some fine material (i.e., silt and finer) is washed into deep water in Burrard Inlet $\left(V_{\mathrm{dw}}\right)$.

Combining these relations, an interpreted sediment budget can be written as

$$
\left(\rho_{\mathrm{hsl}} V_{\mathrm{hsl}}-\rho_{\mathrm{fsl}} V_{\mathrm{fsl}}\right)-\left(\rho_{\mathrm{str}} \Delta V_{\mathrm{str}}\right)=\rho_{\mathrm{af}} V_{\mathrm{af}}+\rho_{\mathrm{dw}} V_{\mathrm{dw}}
$$

\section{Approximating landform volumes}

The volume of material eroded from hillslopes was estimated as the volume of sediment removed from interpreted "pre-erosional" surfaces. Gullies running the length of mountainside slopes are the primary erosional features visible on aerial photographs. They are present on rocky and colluviumand till-covered slopes. The gullies are assumed to be formed by weathering of rock and soil material, erosion, and subsequent transfer of material downslope through mass wasting, principally debris flow (Benda and Dunne 1987). For volumetric calculations it is assumed that a triangular prism estimates the shape of gullies, since gullies observed in the field have similar, triangular cross sections for extended slope lengths. The amount of sediment mobilized from that source is assumed to be the volume of the gully (Fig. 3), represented as

$$
V_{\text {gully }}=\frac{\mathrm{wdl}}{2 \cos \theta_{\mathrm{sl}}}
$$

where $V_{\text {gully }}$ is the volume of the gully $\left(\mathrm{m}^{3}\right) ; w$ is the average width of the gully $(\mathrm{m}) ; d$ is the average depth of the gully (m), measured perpendicular to the slope; $l$ is the horizontal (i.e., map or aerial photograph) gully length $(\mathrm{m})$; and $\theta_{\mathrm{sl}}$ is the average slope gradient (degrees). Length and width were measured directly from aerial photographs. The width of the 
Fig. 3. Variates for gully volume calculations.

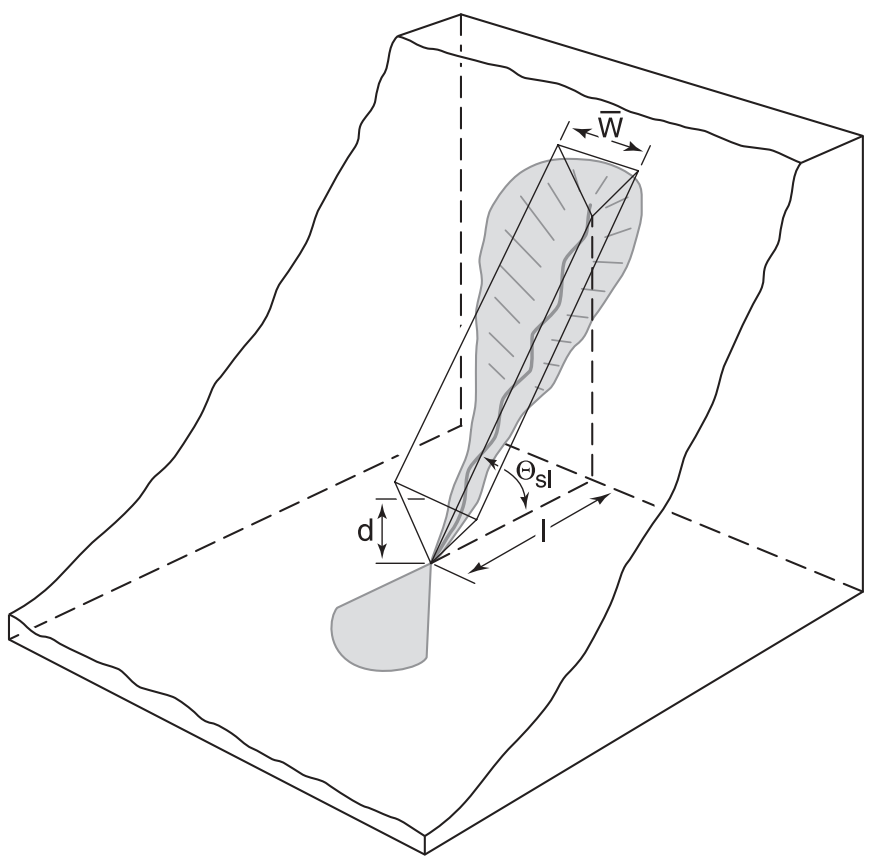

gully was measured as the distance between the top of either side of the gully. Gradient was obtained from the map and depth was estimated from map contours by extending open slope contours across the gully. In total, 294 gullies were recorded.

Colluvial fans along the footslopes approximate a sector of a cone truncated by a plane (the mountainside behind) (Fig. 4):

$$
V_{f a n}=h\left(\theta_{f a n} \bar{r}^{2}-b l\right) / 6
$$

where $V_{\text {fan }}$ is the volume of the fan $\left(\mathrm{m}^{3}\right), h$ is the height of the fan $(\mathrm{m}), \theta_{\text {fan }}$ is the arc angle of the fan (radians), $\bar{r}$ is the average radius of the fan $(\mathrm{m}), b$ is the distance between arc arms of the fan $(\mathrm{m})$, and $l$ is the length of the perpendicular bisector of $\theta_{\text {fan }}$ to segment $b(\mathrm{~m})$. The terms $\theta_{\text {fan }}, \bar{r}, b$, and $l$ were measured from interpreted landforms on aerial photographs, and $h$ was estimated from map contours. The contour interval is $20 \mathrm{~m}$, so $h$ is considered to be interpolated to within $\pm 5 \mathrm{~m}$. The surface of these small fans is commonly near-rectilinear, so no correction has been made for surface concavity. Still, not all fan deposits conformed to "ideal" morphology because adjacent fans tended to overlap. Where a fan did not conform to the ideal shape, estimates of variables were based on interpretation. This relation is used for debris fans and talus cones in the drainage basin and for alluvial fan deposits at the mouth of the five significant tributary creeks feeding into Lynn Creek. A total of 70 features were recorded.

Talus footslopes have developed by the accumulation of rockfalls and rockslides from steep bedrock slopes. Talus accumulations tend to create their own near-rectilinear gradient, with steepness reflecting the frictional properties of the material and not being due to underlying bedrock morphology. The underlying bedrock was assumed to be a continuous slope beneath the talus. The volume of material in the deposit can be estimated by a triangular prism (Fig. 5):
Fig. 4. Variates for colluvial fan volume calculations.

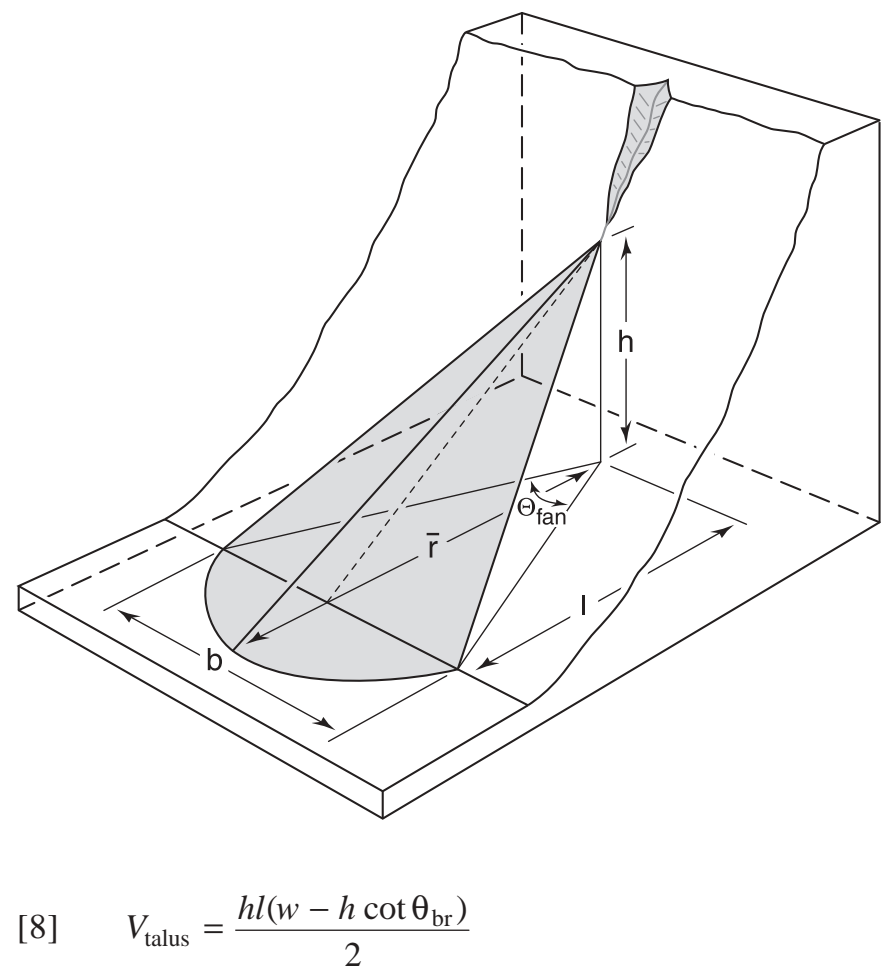

where $V_{\text {talus }}$ is the estimated volume of material in the talus slope $\left(\mathrm{m}^{3}\right), l$ is the average length of the talus slope $(\mathrm{m}), w$ is the average width of the deposit $(\mathrm{m}), h$ is the average height of the landform $(\mathrm{m})$, and $\theta_{\mathrm{br}}$ is the average slope of the underlying bedrock (degrees) (Fig. 5). The terms $w$ and $l$ were measured on aerial photographs, and $h$ and $\theta_{\mathrm{br}}$ were obtained from the map. The second term in the numerator of eq. [8] represents a correction based on the assumption that the gradient of buried bedrock under the talus is the same as the gradient of the bedrock directly upslope of the talus deposits. Twelve such features, varying from 100 to $700 \mathrm{~m}$ in length along the valley side, were identified and measured.

Failures in glaciolacustrine material at the south end of the drainage basin are quite apparent on aerial photographs. The failures are propagated by springline sapping. We assume, then, that the failed slopes have gradients similar to that of the terrace front scarp, reflecting the strength of the lacustrine material. Their geometry is similar to that of hillslope gullies (Fig. 6), and eq. [6] is assumed for volume calculations to yield $\Delta V_{\mathrm{gl}}$, the estimated volume of sediment from glaciolacustrine failure $\left(\mathrm{m}^{3}\right)$. Length measurements are made on the photograph from the head of the failure to the prefailure terrace edge (interpreted based on the location of the terrace edge adjacent to the failures). The depth of the failures is the height of the terrace $(20 \mathrm{~m})$. Since they are directly adjacent to Lynn Creek, it is assumed that all of the failed material entered the fluvial system. Thirty-four features were recorded.

During the postglacial period, Lynn Creek has been in a net degradational regime, as demonstrated by the paired terraces on either side of the creek. Similar postglacial degradational regimes have been observed in valleys adjacent to Lynn Valley (Lian and Hickin 1996). Channel degradation is considered to be the net sediment yield due to channel downcutting. 
Fig. 5. Variates for talus slope volume calculations.

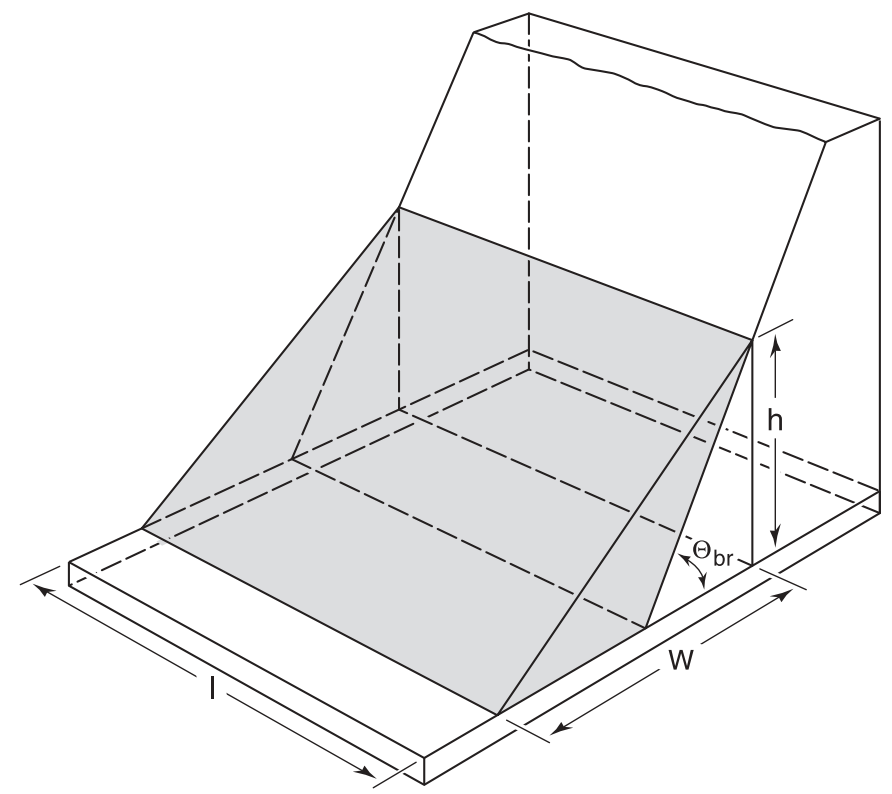

Again, this transfer is not process specific. Degradation can occur by channel and bank erosion or by mass-wasting processes, such as soil creep or landsliding, acting on slopes immediately adjacent to the stream.

The terraces indicate the pre-erosional surface of valley fill, so the void of material between the terraces represents the volume that has been lost. The volume of eroded material can be estimated by a trapezoidal prism (Fig. 7) such that

$$
V_{\mathrm{cd}}=\frac{h l\left(w_{\mathrm{fp}}+w_{\mathrm{tr}}\right)}{2}
$$

where $V_{\mathrm{cd}}$ is the estimated volume of channel degradation $\left(\mathrm{m}^{3}\right), w_{\mathrm{fp}}$ is the width of the floodplain $(\mathrm{m}), w_{\mathrm{tr}}$ is the distance between terrace edges $(\mathrm{m}), h$ is the average height of terraces (m), and $l$ is the length of the channel (m). Lynn Creek (and its principal tributaries) was divided into 35 arbitrary segments of approximately $400 \mathrm{~m}$ each in length. These reaches covered the length of channel where terraces were
Fig. 6. Variates for failure volumes in the glaciolacustrine terraces.

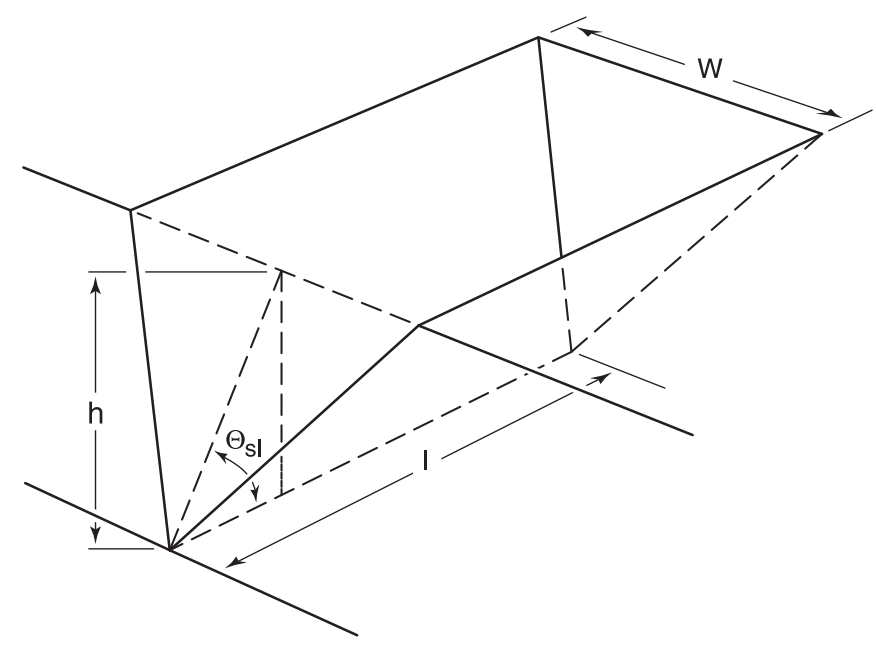

present, and hence represented the region of channel degradation. Variables and volume calculations were made for each segment, and the total volume was calculated based on the sum of volumes from all 35 segments.

The mouth of Lynn Creek has developed an alluvial fan into Burrard Inlet by the deposition of discharged sediment. It is the ultimate sink of sand and coarser sediments from Lynn Creek and is assumed to have developed over postglacial time. A cone-shaped geometry is used to estimate the volume of the subaerial alluvial fan (eq. [7]). The underlying delta is estimated as a segment of a disc, $V=h \bar{r} \theta_{\text {fan }} / 2$.The underlying bedrock dips into the inlet at about $4^{\circ}$; accordingly, a pyramid with this front slope is subtracted from the estimated volume. The fan deposit was interpreted, and measurements for all variables were made, on topographic and bathymetric maps.

\section{Synthesis of results}

By using mass estimates from all the sources, a sediment budget can be constructed for the watershed. Rewriting eq. [5], the sediment budget for the drainage basin over the postglacial time period can then be written as

$[10 a] \rho_{\text {hsl }} \Sigma V_{\text {gully }}+\rho_{\text {rock }} \Sigma V_{\text {rock }}-\left(\rho_{\text {fan }} \Sigma V_{\text {fan }}+\rho_{\text {talus }} \Sigma V_{\text {talus }}\right)+\rho_{\text {gl }} \Sigma V_{\text {gl }}+\rho_{\text {cd }} \Sigma V_{\text {cd }}=\rho_{\text {af }} V_{\text {af }}+\rho_{\text {aw }} V_{\text {dw }}$

where $\rho_{\text {rock }}, \rho_{\text {fan }}, \rho_{\text {talus }}, \rho_{\mathrm{gl}}$, and $\rho_{\mathrm{cd}}$ are bulk densities of rock, footslope, debris fan, talus, glaciolacustrine, and terrace materials, respectively. Isolating the sand and coarser material, such that $\alpha, \beta$, and $\gamma$ represent the fraction of coarse particles in hillslope, glaciolacustrine, and channel fill materials, respectively, the coarse material budget is

$$
\rho_{\text {rock }} \Sigma V_{\text {rock }}+\alpha\left(\rho_{\text {hsl }} \Sigma V_{\text {gully }}-\rho_{\text {fan }} \Sigma V_{\text {fan }}-\rho_{\text {talus }} \Sigma V_{\text {talus }}\right)+\beta \rho_{\text {gl }} \Sigma V_{\text {gl }}+\gamma \rho_{\text {cd }} \Sigma V_{\text {cd }}=\rho_{\text {tf }} V_{\text {tf }}
$$

A comparison is therefore made between the estimated output of sediment from all sources and the estimated volume of the terminal alluvial fan deposit. It is assumed that much of the mobilized fine material has been exported into deep water in Burrard Inlet. For practical purposes, "fine material" is assumed to be silt and clay. It is assumed that physical and chemical breakdown of coarse material is negligible.

\section{Contemporary sediment transfers}

"Contemporary" refers to the current regime of sediment transfer within the drainage basin. Direct measurement of all sediment transfer mechanisms is not feasible on a synoptic basis. Debris flows and slides are the only contemporary events that are detected using aerial photograph analysis. These processes occur dominantly within gullies. Rates of tree throw, sheet wash, and bank erosion are estimated based on field studies in the region. Other processes (e.g., snow 
Fig. 7. Variates for channel degradation volume calculations. See eq. [9].

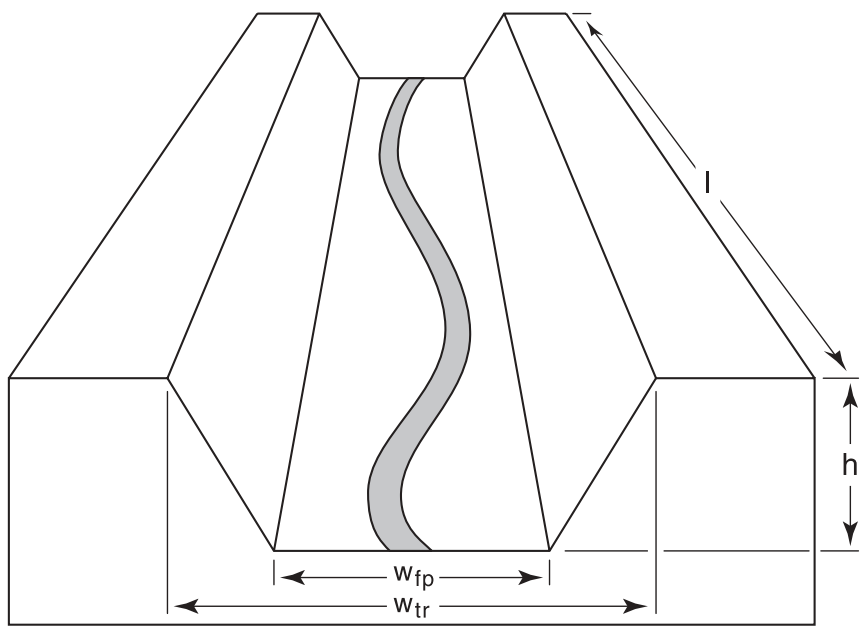

avalanche and animal disturbance) are assumed to yield negligible volumes of sediment.

A methodology similar to that used by Martin et al. (2002) is applied in this study to estimate the volume of mass-wasting events using aerial photograph analysis. A total of 195 landslides are visible on 1996 province of British Columbia aerial photographs, based on evidence of fresh movement (i.e., nonvegetated scars). Failures were separated into two segments, the initiation-transport zone and the deposition zone. Deposition of debris flows in the southern Coast Mountains has been observed to occur on slopes of $10-12^{\circ}$ (Hungr et al. 1984). Precise depositional zones are difficult to resolve with the resolution of aerial photographs, so deposition of failures was assumed to occur on slopes of $12^{\circ}$ or less (observed on topographic maps). The upslope initiation-transport zone is the region of sediment mobilization. The volume of material mobilized by a debris flow was computed as

$$
V_{\text {failure }}=\frac{w l d}{\cos \theta_{\mathrm{sl}}}
$$

where $V_{\text {failure }}$ is the volume of sediment mobilized in the debris flow or slide event $\left(\mathrm{m}^{3}\right), w$ is the average width of the failure $(\mathrm{m}), d$ is the average depth perpendicular to the slope (m), $l$ is the horizontal (map) length $(\mathrm{m})$, and $\theta_{\mathrm{sl}}$ is the average slope gradient (degrees). Visible signs of fresh movement on aerial photographs define an event, and length and width measurements were made on aerial photographs based on this signature. The initiation-transport zone is assumed to be divided into $25 \%$ initiation zone and $75 \%$ transport zone. Field measurements on 37 slides yielded an average depth in the initiation zone of $1.0 \mathrm{~m}$ (standard deviation $\pm 0.8 \mathrm{~m}$ ), consistent with results of Acres International Ltd. (1997) in adjacent basins. The consistency arises from the fact that failures normally occur at the base of weathered till, and the Holocene weathering front is about $1 \mathrm{~m}$ deep on most sites. For volume calculations the scour depth in the initiation zone is assumed to be $1.0 \mathrm{~m}$, and the depth in the transport zone is assumed to be half the depth of the initiation zone $(0.5 \mathrm{~m})$.

In terms of the sediment budget equation, the volume of sediment mobilized in debris flows or slides represents the input, $I$. Some of the material is deposited within the deposition zone $(\Delta S)$, and the rest may be introduced into the stream system $(O)$. Due to the scale of the photographs and vegetation cover, the deposition zone of slides could not always be identified or delineated. The amount of material delivered to the stream system from each debris flow or slide was therefore estimated as a fraction $(\eta=0.10,0.33,0.66$, or 1.00$)$ of volume mobilized from the initiation-transport zone, based on the ratio of the initiation-transport zone length to the distance between the deposition zone and the stream. Where this ratio was large (initiation-transport length much greater than distance of deposition zone to the stream channel), $\eta$ was assigned a larger value ( 0.66 or 1.00$)$ than if this ratio was small.

It is assumed on the basis of investigations in the region that landslides remain visible on aerial photographs (i.e., not completely revegetated) for up to 40 years (Brardinoni et al. 2002). Landsliding rate is then determined as the volume of landslide material divided by the 40 year average age.

Other types of contemporary sediment transfer mechanisms are tree throw, sheet wash, and fluvial bed and bank erosion. These are comparatively continuous processes. Measurements of the rates of such phenomena are not feasible from aerial photographs or from measurements of morphology. Field measurements require lengthy study periods because of the relatively slow rates of movement. Such measurements were not within the scope of this synoptic study. Instead, process rates are estimated based on published regional data. For purposes of assessing sediment delivery, soil creep, which is an important process on steep, soil-mantled slopes, is subsumed into bank erosion along stream channels.

We can make a more specific inference about net fluvial sediment output of bed material because of the presence of a weir built in the early 20th century near the mouth of the mountain valley which indicates that there has been negligible change in bed elevation since. In addition, the floodplain upstream carries mature forest, yet is still active, and nonfluvial materials are exposed at some places in the streambed. These are further indications of a vertically stable channel. Between the weir and the head of the terminal alluvial fan, Lynn Creek flows through a bedrock canyon in which there is little resident sediment.

\section{Data and analysis}

\section{Postglacial sediment budget}

Sediment transfers from postglacial erosion are summarized in Table 1. To transform the measured volumes into masses for the purposes of summation, bulk density figures are required. Only rock (talus) sources can be assigned a firm figure. Source sediments in upper slope gullies are assumed to have a bulk density of $2000 \mathrm{~kg} \cdot \mathrm{m}^{-3}$, the preponderance being derived from glacial till, for which a range of values between 1850 and $2150 \mathrm{~kg} \cdot \mathrm{m}^{-3}$ are commonly reported (Bell 1981; Williams 1982). Coast Mountain tills are sandy and contain a moderate volume of coarse clasts, so median values should be representative. The fan deposits and valley alluvial deposits are assigned a bulk density of $1800 \mathrm{~kg} \cdot \mathrm{m}^{-3}$ on the basis of measurements of similar materials by the authors. The glaciolacustrine silts are assigned a similar value on the basis of tabulated results for cohesive soils (Bell 1981). The 
Table 1. Postglacial sediment transfers in Lynn Valley.

\begin{tabular}{|c|c|c|c|c|c|c|c|c|}
\hline Sediment source & Term & $\begin{array}{l}\text { Sediment volume } \\
\left(\times 10^{6} \mathrm{~m}^{3}\right)\end{array}$ & $\begin{array}{l}\text { Bulk density } \\
\left(\mathrm{kg} \cdot \mathrm{m}^{-3}\right)\end{array}$ & $\begin{array}{l}\text { Sediment mass } \\
\left(\times 10^{6} \mathrm{t}\right)\end{array}$ & $\begin{array}{l}\text { Sediment yield } \\
\text { rate }\left(\mathrm{t} \cdot \mathrm{km}^{-2} \cdot \mathrm{a}^{-1}\right)^{a}\end{array}$ & $\begin{array}{l}\text { Source area } \\
\left(\mathrm{km}^{2}\right)\end{array}$ & $\begin{array}{l}\text { Percentage of total } \\
\text { drainage basin }\end{array}$ & $\begin{array}{l}\text { Measurement } \\
\text { error }(\%)\end{array}$ \\
\hline \multicolumn{9}{|l|}{ Gullies } \\
\hline Identified sources & $\Sigma \Delta V_{\text {gully }}$ & 93 & 2000 & 186 & 304 & 9.1 & $21^{b}$ & \pm 1.6 \\
\hline Footslope fans & $\Sigma \Delta V_{\text {fan }}$ & 69 & 1800 & 124 & & & & \pm 1.3 \\
\hline Output from gullies & $\Sigma \Delta V_{\text {gully }}-\Sigma \Delta V_{\text {fan }}-\Sigma \Delta V_{\text {rock }}$ & & & 62 & 101 & 9.1 & $21^{b}$ & \pm 1.7 \\
\hline \multicolumn{9}{|l|}{ Talus } \\
\hline Identified sources & $\Sigma \Delta V_{\text {rock }}$ & 29 & 2700 & 78 & 127 & & & \pm 1.6 \\
\hline Deposits & $\Sigma \Delta V_{\text {talus }}$ & 39 & 1800 & 70 & & & & \pm 2.6 \\
\hline Output from rockfall & & & & 8 & 13 & & & \pm 2.6 \\
\hline Channel degradation & $\Sigma \Delta V_{\mathrm{cd}}$ & 28 & 1800 & 50 & 82 & 2.5 & 6 & \pm 4.4 \\
\hline Glaciolacustrine deposits & $\Sigma \Delta V_{\mathrm{gl}}$ & 3 & 1800 & 5.4 & 7.7 & 0.3 & 1 & \pm 5.3 \\
\hline Minor processes & $\Sigma \Delta V_{\text {minor }}$ & & & 10 & 16 & & & \\
\hline Estimated output & $\Sigma \Delta V_{\text {gully }}+\Sigma \Delta V_{\text {fan }}+\Sigma \Delta V_{\text {talus }}+\Sigma \Delta V_{\text {gl }}+\Sigma \Delta V_{\text {cd }}$ & & & 135 & 220 & & & \pm 3.0 \\
\hline Coarse material output & $\alpha\left(\Sigma \Delta V_{\text {gully }}+\Sigma \Delta V_{\text {fan }}+\Sigma \Delta \Delta_{\text {Vtalus }}\right)+\beta \Sigma \Delta V_{\text {gl }}+\gamma \Sigma \Delta V_{\text {cd }}$ & & & 115 & 187 & & & \\
\hline Terminal alluvial fan-delta & $\Sigma \Delta V_{\mathrm{af}}$ & & & & & & & \\
\hline Subaerial & & 42 & 1800 & 76 & & & & \pm 23 \\
\hline Subaqueous & & 82 & 1600 & 139 & & & & \pm 28 \\
\hline Total & & & & $215^{c}$ & & & & \\
\hline
\end{tabular}

${ }^{a}$ Yield rate per $\mathrm{km}^{2}$ of total drainage basin area $\left(43.7 \mathrm{~km}^{2}\right)$.

${ }^{b}$ Fraction quoted is area occupied by gullies, within which repeated events occur.

${ }^{c}$ Range $=161-269$. 
Table 2. Estimates of contemporary erosion rates.

\begin{tabular}{lccl}
\hline Sediment source & Sediment yield rate $\left(\mathrm{m}^{3} \cdot \mathrm{km}^{-2} \cdot \mathrm{a}^{-1}\right)^{a}$ & Mass $\left(\mathrm{t} \cdot \mathrm{km}^{-2} \cdot \mathrm{a}^{-1}\right)$ & Data source \\
\hline Debris slides and flows (gullies) & 170 & 340 & This study \\
Tree throw & $1-10$ & $2-18$ & Roberts and Church 1986 \\
Sheet wash & $4-10$ & $6-16$ & Roberts and Church 1986 \\
Bank erosion & $1-5$ & $2-9$ & Reid 1981; Lehre 1982 \\
Streambed erosion & 0 & & This study \\
Total estimated & $176-195$ & & \\
\hline
\end{tabular}

${ }^{a}$ Yield rate per $\mathrm{km}^{2}$ of the total drainage basin area.

terminal fan is assigned a value of $1800 \mathrm{~kg} \cdot \mathrm{m}^{-3}$ for the subaerial portion, but $1600 \mathrm{~kg} \cdot \mathrm{m}^{-3}$ for the subaqueous portion.

Gullies represent erosional landforms with fairly distinct boundaries, and volume calculations can be made with confidence. The smallest landslides under tree cover are not detected on aerial photographs, however. Brardinoni and Church (in press) have shown by a combined air and ground survey in the adjacent drainage basin that the censored small failures are not volumetrically significant. Erosion from rockfall on open slopes is also difficult to assess because there is no way of interpreting a "pre-erosional" surface. The granodiorite is competent, and sources on open slopes are restricted to block quarrying by freeze-thaw from exposed ends of exfoliation sheets. Joint-plane gullies on open slopes were assumed to be the source regions for talus deposits. In the outcome, the quantity stored in footslopes appears to be slightly smaller than measured input from source areas. Since little talus material reaches the channel, the quantities observed are assumed to be correct. In any case, errors in talus assessment are not propagated farther through the sediment budget. The balance of the landforms were measured in a relatively straightforward manner. It is possible that surface wash and fluvial transport are significant in the unvegetated gullies, and minor processes must have made a cumulatively significant contribution over 14000 years. Simply multiplying up the current estimated rate of minor processes (see Table 2) yields a contribution of about $10 \times 10^{6}$ t. Tabulated sediment yield rates are based on total sediment per square kilometre of total drainage basin per year, including the volumes of sediment mobilized from gullies, hillslopes, and channel degradation.

Glacigene materials are assumed to be $20 \%$ fine fraction (i.e., silt and clay) by weight on the basis of samples derived from the immediately adjacent valleys (Acres International Ltd. 1997; J.M. Ryder, personal communication, February 2000). Applying this fraction to hillslope and channel fill material results in $\alpha=0.8$. Channel fill materials are assumed to have $\gamma=1.0$. Glaciolacustrine deposits are approximately $90 \%$ fine fraction by volume (Acres International Ltd. 1997), therefore $\beta=0.1$. The estimated output from the basin is $135 \times$ $10^{6} \mathrm{t}\left(115 \times 10^{6} \mathrm{t}\right.$ of coarse material $)$, representing a yield rate of $220 \mathrm{t} \cdot \mathrm{km}^{-2} \cdot \mathrm{a}^{-1}$. Errors associated with the measurements can be appraised. Since the calculations are linear, the fractional error estimate for a single landform is $\delta V / V=\left[\Sigma\left(\delta x_{\mathrm{i}} / x_{i}\right)^{2}\right]^{1 / 2}$, where $\delta x_{i}$ is the estimated error of the dimension $x_{i}$. The $x_{i}$ are variously lengths, widths, heights, arc angles, and mass densities. The landform dimensions entered into this formula were median estimates for all the measurements made on a class of landforms. Errors vary between 10 and 30\%. For the total volume contributed by a particular landform, errors are reduced by $(n)^{1 / 2}$, the number of landforms in the group. This yields summary errors for the cumulated totals, reported in Table 1 , on the order of $1-5 \%$, except for the terminal fan, of which there is only one unit. These calculations do not cover the bias that may remain in the results, which has been estimated to be on the order of $\pm 5 \%$.

The measured output from source areas is about $65 \%$ of the best volume estimate for the terminal fan $\left(215 \times 10^{6} \mathrm{t}\right)$. There are several reasons why this discrepancy might arise, mainly concerning the measurement of the fan. First, we do not know the actual bedrock contour under the fan or whether the fan is deposited on top of older sediments. Second, we do not know whether a portion of the sediments under the surface of the Lynn Creek fan might have emanated from Seymour River. Third, we do not know the fraction of fines contained in the subaqueous portion of the fan-delta. In fact, if all of the fine material estimated to have been mobilized in the basin $\left(45 \times 10^{6} \mathrm{t}\right)$ was sequestered there, then the fine fraction would constitute $20 \%$ of the subaqueous fan. This still leaves a substantial bias between the two summary estimates.

Gullies are the most important in terms of sediment production at an estimated rate of $304 \mathrm{t} \cdot \mathrm{km}^{-2} \cdot \mathrm{a}^{-1}$, of which $111 \mathrm{t} \cdot \mathrm{km}^{-2} \cdot \mathrm{a}^{-1}$ is exported. Channel degradation is also quite important for sediment production at $82 \mathrm{t} \cdot \mathrm{km}^{-2} \cdot \mathrm{a}^{-1}$, accounting for more than a third of total output. Most of the channel degradation is likely to have occurred thousands of years ago, however. Lian and Hickin (1996) report that the neighbouring Seymour River had reached its present grade by about $5000 \mathrm{BP}$.

Although the relative importance of source areas can be observed, the physical processes involved in the transfer of sediment in earlier Holocene time can only be inferred. Gullies tend to deliver sediment by means of debris flows or debris slides, though complex sequences of weathering and sediment transport are involved in slope-to-slope and slope-to-stream transfers. There are similar difficulties distinguishing dominant processes responsible for channel degradation, whether sediment entrainment by the stream or sediment delivery to the stream from adjacent banks by mass wasting on slopes immediately adjacent to the stream channel. The presence of debris slide earth in the glaciolacustrine deposits adjacent to the channel suggests that direct delivery of sediment through mass wasting has been important while, in the contemporary period, sediment appears to be delivered from terrace deposits to the stream channel by mass wasting more than by direct bank erosion

\section{Contemporary sediment transfers}

The bulk of the calculations for contemporary sediment 
Table 3. Comparison of sediment yields from debris slides and flows with other data.

\begin{tabular}{lccc}
\hline Source & $\begin{array}{c}\text { Sediment mobilized } \\
\left(\mathrm{m}^{3} \cdot \mathrm{km}^{-2} \cdot \mathrm{a}^{-1}\right)\end{array}$ & $\begin{array}{c}\text { Sediment transfer to } \\
\text { stream }\left(\mathrm{m}^{3} \cdot \mathrm{km}^{-2} \cdot \mathrm{a}^{-1}\right)\end{array}$ & $\begin{array}{l}\text { Density of failures } \\
\left(\text { no. of failures } / \mathrm{km}^{2}\right)\end{array}$ \\
\hline $\begin{array}{l}\text { Lynn Valley } \\
\text { This study (postglacial) }\end{array}$ & 93 & 34 & 6.7 \\
This study (contemporary) & 330 & 170 & 4.4 \\
North Vancouver - Howe Sound local region & & 13.3 \\
$\begin{array}{l}\text { Brardinoni et al. 2002 } \\
\text { O'Loughlin 1972 }\end{array}$ & 6450 & 215 & - \\
Queen Charlotte Islands (northern British Columbia) & - \\
Martin et al. 2002 & 11 & 25 & 4.5 \\
Rood 1984 & 100 & 16 & - \\
\hline
\end{tabular}

transfers were made for debris flows and debris slides, since these features are measurable on aerial photographs and have been identified as the principal means of mass wasting from mountain slopes in the region (Slaymaker and McPherson 1977; Roberts and Church 1986; Martin et al. 2002). The magnitude of tree throw, sheet wash, and stream bank erosion was assessed using published regional data sources. Geomorphic, geological, and climatic conditions in Lynn Valley are typical of the region, therefore it seems reasonable to assume similar process rates. Estimates of contemporary erosion are given in Table 2. The quoted errors are estimated errors of measurement, constructed as described for the results in Table 1.

Tree throw is a slow process, with rates on the order of $10^{-3}-10^{-2} \mathrm{~m} \cdot \mathrm{a}^{-1}$ (from Roberts and Church 1986) or approximately $1-10 \mathrm{~m}^{3} \cdot \mathrm{km}^{-2} \cdot \mathrm{a}^{-1}$. Sheet wash is a function of rainfall, vegetation cover, soil characteristics, topography, and land use and mobilizes on the order of $4-10 \mathrm{~m}^{3} \cdot \mathrm{km}^{-2} \cdot \mathrm{a}^{-1}$ (summary of regional data in Roberts and Church 1986) from forested slopes, where surface erosion is minor because of the minimal extent of exposed soil and high surface infiltration rates. Bank erosion rates along forested streams have been measured to be in the range of $2-11 \mathrm{~m}^{3} \cdot \mathrm{km}^{-1}$ channel length (Reid 1981; Lehre 1982, from measurements in the Washington Cascades). The total length of higher order stream channels in Lynn Valley is approximately $20 \mathrm{~km}$ (third order and higher on the map). It is assumed that this represents the stream channels contributing significant amounts of sediment from bank erosion, lower order streams being stable or dominated by mass-wasting processes. Bank height is typically about $1 \mathrm{~m}$, therefore an approximate yield rate from bank erosion would be $1-5 \mathrm{~m}^{3} \cdot \mathrm{km}^{-2} \cdot \mathrm{a}^{-1}$.

The processes of bed erosion and bed load transport are difficult to separate. Accumulation or removal of stored bed material occurs by channel aggradation or degradation. Different reaches of a stream may be aggrading or degrading because of local sediment supply and other channel conditions, however. A weir was constructed across Lynn Valley above Lynn Canyon (ca. 1940). Local degradation of the channel to bedrock has occurred for $15 \mathrm{~m}$ directly downstream of the weir. Directly upstream of the weir is local accumulation of material. This suggests local readjustment of the channel in response to the weir. Throughout the rest of the creek length, the channel bed is well armoured and there are no evident signs of recent scouring of the bed. These observations suggest that net bed erosion is near zero in contemporary time.
Analysis of debris flows and debris slides gives a yield rate to streams of $170 \mathrm{t} \cdot \mathrm{km}^{-2} \cdot \mathrm{a}^{-1}$. A comparison of the debris flow sediment mobilization has been made with other regional data (Table 3). Landsliding rates in Lynn Valley are comparable with results reported from a detailed study in neighbouring Capilano watershed (Brardinoni et al. 2002) but are higher than other measured regional rates. The yield of debris slides and flows, based on measurements in the valley, is an order of magnitude larger than the sum of all other processes considered and appears, therefore, to provide a reasonable basis for a contemporary sediment budget.

\section{Comparison of postglacial and contemporary sediment transfers}

A significant difference arises between the postglacial and contemporary sediment budgets in the relative contribution of the two dominant sources. Gullies account for $46 \%$ of the total sediment yield in the postglacial period, whereas debris flows and slides from gullies account for $90 \%$ or more of the contemporary yield. The contribution of contemporary bed and bank erosion is of a lower magnitude than that estimated for postglacial degradation $\left(10^{1}\right.$ versus $\left.10^{2} \mathrm{t} \cdot \mathrm{km}^{-2} \cdot \mathrm{a}^{-1}\right)$. This apparent variation could be a result of the difficulty to assess the processes responsible for long-term degradation by the stream channel. It is plausible that there have been changes in the rates of processes through time due to changing regimes of sediment yield and channel stability, however. The channel probably stabilized several thousand years ago after major degradation through the fine-grained glaciolacustrine deposits at the south end of the basin. Today, the channel bed is well armored. Overall, hillslope transfers appear to be the dominant source of sediment inputs on both the postglacial and contemporary time scales. This result has been suggested by other studies in steep forested drainage basins in the region (e.g., Slaymaker and McPherson 1977; Roberts and Church 1986).

Nevertheless, the overall sediment yield rates are estimated to be very similar, and this is superficially startling. Early postglacial sediment yields are supposed to have been much larger than recent yields (Church and Ryder 1972). The long integration period of the postglacial budget presents a problem for comparison. This matter has been investigated systematically by Gardner et al. (1987), who found a consistent scaling effect, $\Delta t^{0.815 \pm 0.104}$, for estimates of surface denudation as time scale expands from 1 year to the order of $10^{8}$ years. 
This effect might be expected to arise from the dynamics of sediment production, storage, and episodic evacuation (see Clapp et al. 2000 for a specific example). Application of this scaling factor would imply that the true postglacial denudation rate might be 2.5 to 16 times higher than the observed result (the result is very sensitive to the scaling exponent, which is known only to within \pm 0.1 ).

Kirchner et al. (2001) found that denudation measured in small drainage basins in central Idaho, summed over 10000 years by cosmogenic dating, was on average 17 times larger than contemporary fluvial sediment yield rates based on records of 10-84 years length. The drainage basins are steep and the authors assert that there is little opportunity for long-term sediment storage that might upset the comparison between sediment production and sediment yield. Based on space and time scales, and on topography, the comparisons of Kirchner et al. are superficially very similar to those of the present study. The mass-wasting processes enumerated by Kirchner et al. are also similar to those experienced in Lynn Valley, although the Idaho basins lie beyond the glacial limit. The authors ascribed the discrepancy between the two sets of estimates to the significance of individual, rare instances of very large sediment delivery, not captured in the comparatively short records of direct observation. Jordan and Slaymaker (1991; see also Slaymaker 1993) observed a similar phenomenon in the $3150 \mathrm{~km}^{2}$ Lillooet valley, about $100 \mathrm{~km}$ north of Lynn Valley, where the discrepancy between estimated sediment yield rates and accumulated Holocene sediments is about 0.5 times and ascribed the effect to substantially increased paraglacial sediment yield. In the present case, however, we have a reasonable agreement between apparent denudation and extant deposits which seems to preclude a large magnification of denudation unless the evacuated sediments have been very much finer than estimated (so a great deal has been lost to deep water).

The Holocene history of Lynn Valley is likely very similar to that of neighbouring Seymour Valley, documented by Lian and Hickin (1996), who found that the early period of accelerated paraglacial sedimentation was largely complete by about $9000 \mathrm{BP}$ (uncalibrated radiocarbon date). They also noted that a significant part of that sedimentation appears to have been associated with the transition of earliest Holocene cool, wet conditions to the xerothermic conditions of the period between 10000 and 7000 BP. The presence of charcoal in fan deposits indicates that slope instability aggravated by fire may have been a significant mechanism promoting sediment mobilization. After $7000 \mathrm{BP}$, increasingly cool and moist conditions probably promoted a stable forest cover that reduced sediment yields in late Holocene time. The appearance of industrial society within the last 150 years, with extensive forest harvest, has upset the late Holocene sediment balance. A speculative sketch of the Holocene sediment history is given in Fig. 8. The long-term average sediment yield is considered to be substantially influenced by rapid sediment delivery from unstable slopes during the earliest Holocene paraglacial period, the equivalent of a period of major instability as defined by Kirchner et al. (2001; see also Schumm and Rae 1995). Contemporary sediment yields may approximate the long-term average as the result of recent land disturbance. The similarity of the actual estimated rates probably is fortuitous (and may merely be the consequence of our
Fig. 8. Schematic Holocene sediment yield pattern for Lynn Valley. The curve is drawn under the following assumptions: the pattern of transient postglacial sediment yield is a decaying exponential function, $a \mathrm{e}^{-x t}$; the initial deglacial sediment yield was $a=$ $1300 \mathrm{~m}^{3} \cdot \mathrm{km}^{-2} \cdot \mathrm{a}^{-1}$ (i.e., approximately 10 times the long-term mean of $143 \mathrm{~m}^{3} \cdot \mathrm{km}^{-2} \cdot \mathrm{a}^{-1}$ less the steady state yield rate); steady state yield from forested terrain in the region is $10 \mathrm{~m}^{3} \cdot \mathrm{km}^{-2} \cdot \mathrm{a}^{-1}$ (O'Loughlin 1972, who worked in nearby Howe Sound). This gives a transient rate constant $x=3.5 \times 10^{-4}$. Non-exponential fluctuations in the transient rate are not known and not graphed.

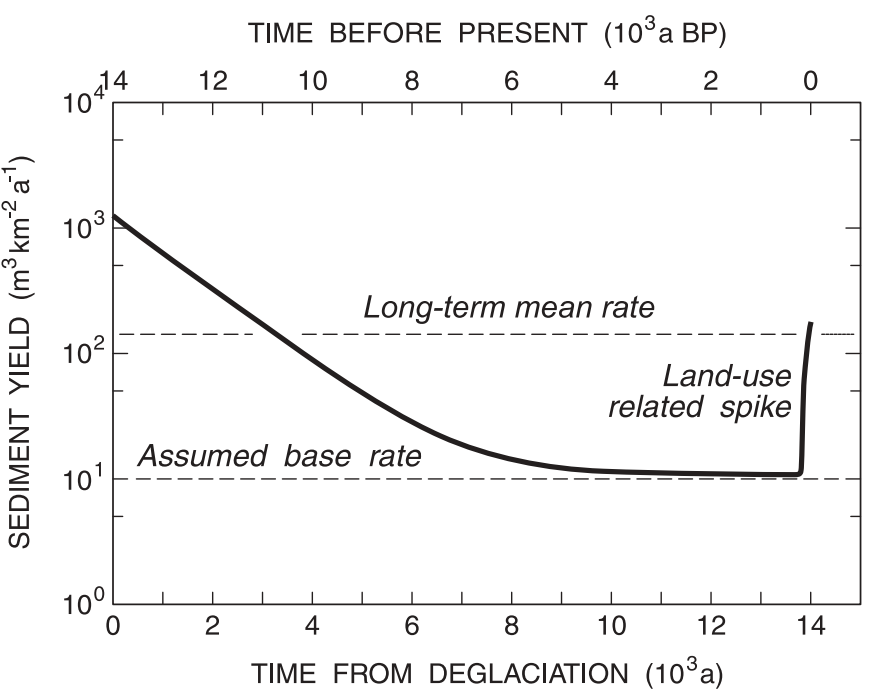

reconnaissance methods of analysis) and should not be expected in general.

\section{Conclusions}

On the postglacial time scale, sediment has been mobilized in Lynn Valley predominantly from hillslope gullies and from valley-flat degradation. Gullies occupy $21 \%$ of the drainage area and mobilized sediment at a rate on the order of $3 \times$ $10^{2} \mathrm{t} \cdot \mathrm{km}^{-2} \cdot \mathrm{a}^{-1}$. Channel degradation was also significant for sediment mobilization, with about $6 \%$ of the drainage basin contributing. Estimated sediment output from source areas constitutes $63 \%$ of the estimated volume of the alluvial fan in Burrard Inlet. The difference most likely arises from errors in assessing the volume of Lynn Creek sediments present in the fan, but undoubtedly subsumes other biases left in the accessible record. The comparison nevertheless suggests that the expected source areas are indeed the main contributors of sediment within the drainage basin.

Examination of the contemporary sediment regime indicates that the mobilization of sediment to streams by landslides is about $340 \mathrm{t} \cdot \mathrm{km}^{-2} \cdot \mathrm{a}^{-1}$. This rate is larger than other measurements that have been made for landslide sediment mobilization in the region (Table 3). Soil creep, sheet wash, and bed and bank erosion contribute on the order of $10 \mathrm{t} \cdot \mathrm{km}^{-2} \cdot \mathrm{a}^{-1}$ of sediment, suggesting that landslide mobilization is an order of magnitude more significant than other sources. From the apparent sediment yield rates from the examined sources, the erosion rate for Lynn Valley would be on the order of $10^{2} \mathrm{~m}^{3} \cdot \mathrm{km}^{-2} \cdot \mathrm{a}^{-1}\left(0.1 \mathrm{~mm} \cdot \mathrm{a}^{-1}\right.$ of surface lowering $)$.

The methods employed in this study appear to constitute an effective means to establish an approximate sediment 
budget over significant land areas (order 100-1000 km²) and intermediate scales of geomorphological time (on the order of $1000-10000$ years). The apparent correspondence between Holocene and contemporary sediment yield rates, coupled with a qualitative knowledge of the pattern of Holocene sediment yield pattern, shows that there has been a complex history of sediment yield in postglacial time. This confounds any assumption of simple patterns of landscape denudation over long periods and presents significant challenges for modeling long-term sediment yield.

\section{Acknowledgments}

We thank Paul Jance for preparing the diagrams and Andre Zimmermann for field assistance. We also thank Dirk deBoer and an anonymous referee for careful reviews that prompted substantial improvements in the paper.

\section{References}

Acres International Ltd. 1997. GVRD watershed ecological inventory program: methodology report. Report prepared for the Greater Vancouver Regional District. Acres International Ltd., Vancouver, B.C.

Armstrong, J.E., and Hicock, S.R. 1979. Surficial geology of Vancouver, British Columbia.. Geological Survey of Canada, Map 1486A, scale 1: 50000.

Bell, F.G. 1981. Engineering properties of soils and rocks. Butterworths, Sevenoaks, U.K.

Benda, L., and Dunne, T. 1987. Sediment routing by debris flow. In Erosion and sedimentation in the Pacific Rim. Edited by R.L. Beschta, T. Blinn, G.E. Grant, F.J. Swanson, and G.G. Ice. International Association of Hydrological Sciences, Publication 165, pp. 213-223.

Brardinoni, F., and Church, M. In press. Representing the landslide magnitude-frequency relation: Capilano River basin, British Columbia. Earth Surface Processes and Landforms.

Brardinoni, F., Slaymaker, O., and Hassan, M.A. 2002. Landslide inventory in a rugged forested watershed: a comparison between air-photo and field survey data. Geomorphology, DOI: 10.106/ S0169-555(X)(02)003 55-0.

Church, M., and Ryder, J.M. 1972. Paraglacial sedimentation: a consideration of fluvial processes conditioned by glaciation. Geological Society of America Bulletin, 83: 3059-3072.

Clague, J.J., Mathewes, R.W., Guilbault, J.-P., Hutchinson, I., and Ricketts, B.D. 1997. Pre-Younger Dryas resurgence of the southwestern margin of the Cordilleran ice sheet, British Columbia, Canada. Boreas, 26: 261-278.

Clapp, E.M., Bierman, P.R., Schick, A.P., Lekach, J., Enzel, Y., and Caffee, M. 2000. Sediment yield exceeds sediment production in arid region drainage basins. Geology, 28: 995-998.

Costa, J.E. 1984. Physical geomorphology of debris flows. In Developments and applications of geomorphology. Edited by J.E. Costa and P.J. Fleisher. Springer-Verlag, Berlin, Germany, pp. 268-317.

Dietrich, W.E., and Dunne, T. 1978. Sediment budget for a small catchment in mountainous terrain. Zeitschrift für Geomorphologie, Supplementband, 29: 191-206.

Dietrich, W.E., Dunne, T., Humphrey, N.F., and Reid, L.M. 1982. Construction of sediment budgets for drainage basins. In Sediment budgets and routing in forest drainage basins. Edited by F.J. Swanson, R.J. Janda, T. Dunne, and D.N. Swanston. U.S. Department of Agriculture, Forest Service, Pacific Northwest
Forest and Range Experiment Station, General Technical Report PNW-141, pp. 5-23.

Gardner, T.W., Jorgensen, D.W., Shuman, C., and Lemieux, C.R. 1987. Geomorphic and tectonic process rates: effects of measured time interval. Geology, 15: 259-261.

Hungr, O., Morgan, G.C., and Kellerhals, R. 1984. Quantitative analysis of debris torrent hazards for design and remedial measures. Canadian Geotechnical Journal, 21: 663-667.

Innes, J.L. 1983. Debris flows. Progress in Physical Geography, 7: 469-501.

Jackson, J.D. 1965. Vancouver north geology. Geological Survey of Canada, Map 1152A, scale 1: 63360.

Jordan, P., and Slaymaker, O. 1991. Holocene sediment production in Lillooet River basin, British Columbia: a sediment budget approach. Géographie physique et Quaternaire, 45: 45-57.

Kirchner, J.W., Finkel, R.C., Riebe, C.S., Granger, D.E., Clayton, J.L., King, J.G., and Megahan, W.F. 2001. Mountain erosion over 10 yr, 10 k.y., and 10 m.y. time scales. Geology, 29: 591-594.

Kovanen, D.J., and Easterbrook, D.J. 2002. Timing and extent of Allerod and Younger Dryas age (ca. $12500-10000{ }^{14} \mathrm{C}$ yr B.P.) oscillations of the Cordilleran ice sheet in the Fraser Lowland, western North America. Quaternary Research, 57: 208-224.

Lehre, A.K. 1982. Sediment budget of a small Coast Range drainage basin in north-central California. In Sediment budgets and routing in forest drainage basins. Edited by F.J. Swanson, R.J. Janda, T. Dunne, and D.N. Swanston. U.S. Department of Agriculture, Forest Service, Pacific Northwest Forest and Range Experiment Station, General Technical Report PNW-141, pp. 67-77.

Lian, O.B., and Hickin, E.J. 1996. Early postglacial sedimentation of lower Seymour valley, southwestern British Columbia. Géographie physique et Quaternaire, 50: 95-102.

Martin, Y., Rood, K., Schwab, J.W., and Church, M. 2002. Sediment transfer by shallow landsliding in the Queen Charlotte Islands, British Columbia. Canadian Journal of Earth Sciences, 39: 189-205.

O'Loughlin, C.L. 1972. The stability of steepland forest soils in the Coast Mountains, southwest British Columbia. Ph.D. thesis, University of British Columbia, Vancouver, B.C.

Reid, L.M. 1981. Sediment production from gravel-surfaced forest roads, Clearwater basin, Washington. College of Fisheries, Fishery Resources Institute, University of Washington, Seattle, Wash., Final Report FRI-UW-8108.

Reid, L.M., and Dunne, T. 1996. Rapid evaluation of sediment budgets. Catena Verlag GMBH, Reiskirchen, Germany.

Roberts, R.G., and Church, M. 1986. The sediment budget in severely disturbed watersheds, Queen Charlotte Ranges, British Columbia. Canadian Journal of Forest Research, 16: 1092-1106.

Roddick, J.A. 1965. Vancouver North, Coquitlam and Pitt Lake map areas, British Columbia. Geological Survey of Canada, Memoir 335.

Rood, K.M. 1984. An aerial photograph inventory of the frequency and yield of mass wasting on the Queen Charlotte Islands, British Columbia. B.C. Ministry of Forests, Land Management Report 34

Schumm, S.A., and Rae, D.K. 1995. Sediment yield from disturbed earth systems. Geology, 23: 391-394.

Slaymaker, O. 1993. The sediment budget of the Lillooet River basin, British Columbia. Physical Geography, 14: 304-320.

Slaymaker, O., and McPherson, H.J. 1977. An overview of geomorphic processes in the Canadian Cordillera. Zeitschrift für Geomorphologie, 21: 169-186.

Strahler, A.N. 1952. Hypsometric (area-altitude) analysis of erosional topography. Bulletin of the Geological Society of America, 63: 1117-1142.

Stuiver, M., Reimer, P., Bard, E., Beck, J.W., Burr, G.S., Hughen, 
K.A., Kromer, B., McCormac, F.G., van derPlicht, J., and Spurk, M. 1998. INTCAL98 radiocarbon age calibration $24000-0$ cal BP. Radiocarbon, 40: 1041-1083.

Swanson, F.J., Janda, R.J., Dunne, T., and Swanston, D.N. (Editors). 1982. Sediment budgets and routing in forested drainage basins.
U.S. Department of Agriculture, Forest Service, General Technical Report PNW-141.

Williams, P.J. 1982. The surface of the earth: an introduction to geotechnical science. Longman, London. 